\title{
EMOTIONAL INTELLIGENCE AND WORK-LIFE BALANCE: A STUDY OF WORKING WOMEN TEACHERS IN PUBLIC SECTOR UNIVERSITIES Sadaf Naz $^{1}$, Saghir Ahmad ${ }^{2}$, Ayesha Batool ${ }^{3 *}$ \\ ${ }^{1,2}$ Department of Education, Hazara University Mansehra, Pakistan; ${ }^{3 *}$ Assistant Professor, Lahore College for Women University Lahore, Pakistan. \\ Email: ${ }^{1,2}$ saghir.edu786@ gmail.com, ${ }^{3 *}$ drayesharana19@ gmail.com \\ Article History: Received on $13^{\text {th }}$ March 2021, Revised on $20^{\text {th }}$ March 2021, Published on $20^{\text {th }}$ March 2021
}

\begin{abstract}
Purpose of the study: The present study focuses to explore the relationship of emotional intelligence with the work-life balance of working women at the university level in Pakistan. The objectives of the study were: i) to determine the level of emotional intelligence and work-life balance of working women of public sector universities in KP; ii) to find out the relationship between emotional intelligence and work-life balance of working women of the public sector universities in KP.

Methodology: The study was quantitative in nature and the survey method was used to collect data. The population consisted of all working women of public sector universities in KP. The sample of the study consisted of 350 working women randomly selected from 06 universities public sector universities. In this respect, two research instruments were developed one for measuring work-life balance and the second for measuring Emotional Intelligence. Data were collected after seeking consent from the working women. The data were analyzed by using statistical techniques.
\end{abstract}

Main Findings: It was found that the majority of the working women had high emotional intelligence with a high worklife balance. A significant correlation was found between emotional intelligence and the work-life balance of working women. It was concluded that high emotional intelligence leads to a high work-life balance.

Applications of this study: Therefore, it is recommended that university administration may develop such programs and policies that may facilitate employees' work-life balance. Higher authorities may arrange training sessions for stress management which may help employees to reduce their stress and keep balance in their personal and professional life.

Novelty/Originality of this study: The readers may come to know about the emotional intelligence and work-life balance of working teachers especially women in higher institutions and how both factors are correlated.

Keywords: Emotional Intelligence (EI), Work-Life Balance (WLB), Working Women, Teachers.

\section{INTRODUCTION}

Intelligence is a combination of many mental processes directed towards effective adaptation to the environment. Similarly, Kidwell et al. (2011) are of the view that emotions have strong psychological forces that influence the behavior and the related performance of the professionals. It refers to the ability of an individual to use emotions by the time and situation. Emotional intelligence covers a large array of an individuals' social life. Yilmaz et al. (2015) opine that EI covers all of our actions and feelings as they say, whatever we do, wherever we go we carry and act with our feelings. Kirk et al. (2008) believe that Emotional Intelligence refers to the adaptive functioning of interpersonal as well as intrapersonal interaction. Researchers have found that EI is the specific trait that varies from individual to individual and the difference is measurable concerning emotional skills as expounded by Austin et al. (2005).

Frederickson (2003) gives the view that positive emotions at the workplace broaden momentary thought and action which ultimately strengthen individual as well as organizational functioning (p.331). Regarding working people, Friedman and Greenhaus (2000) contend that such individuals wish to address their liabilities at the workplace and in the family to achieve satisfaction and success. Achieving job-domestic balance and related satisfaction level is subservient to redesigning workplace load with the family demands as believes Bailyn, (2006) Greenhaus et al. (2001). Fallon $\underline{(2001)}$ believes that job life balance is the capacity of an employee to maintain balance in his/her time, energy, emotions, personal needs, and the needs of those who provide them profits.

Ruderman et al. (2002) argue that the length of time spend at the workplace has a positive relationship with the level of satisfaction. A balance between work and family demands usher forth better satisfaction especially in case of shorter work time and the consequent enriched work (Barnett, 2006). In such a state of affairs skills and resources are bitterly developed which ultimately enhance an individual's capacity to address work-family difficulties concerns. As a result of the new globalized trends in all walks of life, today women have relatively more vibrant roles in societies around the World. Today women occupy management and executive positions in any given social setup as Kinnear, (2014) and Mostert, (2009) contended. In this respect, du Toit et al. (2017); Pillay et al. (2013); Cavazotte et al. (2012), stated that EI plays a significant role in the life of working females. Emotional Intelligence has considerably enhanced the success level of women leaders and workers on the job place (Jonck \& Swanepoel, 2015). Similarly, emotional intelligence provides a base for enhanced leadership qualities in women as expounded by Chaudhry and Saif, (2012); Anand and Suriyan, (2010); Rahim (2010). 
Despite the traditional line of thinking in the past, today there is a visible paradigm shift regarding the role and status of women in any given social set up around the World. As a result of this changing scenario for women today they are in a far better position to participate in the routine matters ranging from the attainment of higher education to jobs, employment socio-economic, and political participation. Coming down to South Asian societies it can easily be observed that women's role in their respective societies is multi-lateral. They are thought to be primarily responsible for household activities. The situation gets further aggravated for women when they get married as they have to undertake many other responsibilities together with the house-hold. Motherhood determines the degree and level of responsibilities and priorities for women. As a result of the low level of stress and tension, women are in a better position to attain and maintain a balance between work and life (Rajesh et al., 2013).

In Pakistan, women play different roles and responsibilities. Together with the job-related duties they have to address household-related tasks such as; husband care, parents care, and children care. Such type of tangled situation poses serious challenges to the married working women as they have to satisfy all the stakeholders. Any failure in this tangled situation may lead to tension and stress-laden family, the consequences of which are usually very devastating in certain cases.

\section{OBJECTIVES}

1. To determine the level of emotional intelligence and work-life balance of working women of public sector universities in KP.

2. To find out the relationship between emotional intelligence and work-life balance of working women of public sector universities in KP.

\section{LITERATURE REVIEW}

For developing and maintaining more pleasant and attractive environment organizations recruit such types of individuals who are emotionally intelligent to attract and serve the individuals in a pleasant manner which ultimately leads to a better performance of the concerned organization. The importance of EI can be understood from the conclusions of Kalantari et al. (2012) study who articulates that a high level of emotional intelligence paves way for reduced tension and stress that is usually created by a tough working environment.

Gohm and Clore, (2002) expounded a new idea in this respect according to which emotional intelligence in the workplace has the potential to reduce burnout in burnout-prone professions. Schwartz (2011) also found that a sense of positive emotions at the workplace leads to a more positive impact on job attitudes coupled with better productivity. In this connection, an individual's capacity to control and manage work time plays a decisive role to address multiple role demands (Valcour \& Hunter, 2005). Here the findings of Thomas and Ganister (1995) are worth-mentioning who found that a lower level of work time control leads to a less capacity to properly address unforeseen family demands, hence such individuals are more aversive.

Lenaghan et al. (2007) believe that managing emotions are the key to achieve balance in the arena of work-family tugof-war. In this respect, Akintayo (2010) is of the view that those who are emotionally intelligent are in a better position to cope successfully with the challenge of work-family stress and conflicts. Emotionally intelligent peoples have a high level of motivation for work as well as for family demands and have relatively less stress in their routine life. Emotional intelligence is a determining factor in developing and maintaining equilibrium in professional and personal life (Shylaja \& Prasad, 2017).

In today's scenario, women around the world have attained a significant place in every walk of life. They are participating in various socio-cultural aspects of life such as; politics, literature, arts, sports, banking, and finance, etc. Of course, these disciplines need an acceptable level of emotional intelligence where issues of stress, anger, etc. can be well addressed through a better level of emotional intelligence. Emotional Intelligence is a determining factor for enhanced academic and professional performance.

Given, the importance of emotional intelligence in the workplace and family-related issues, it is pertinent to mention that the EI level of the working women may be increased. In this connection, Singh (2010) opines that organizations can raise the level of EI of working women by adopting several of measures and programs such as: enhancing their competence, like people success, system success, and self-success. For the development of this aspect Grant, (2007) suggested training programs to improve the level of emotional intelligence of the working women. To some extent women have got out of the tangled situation that usually hamper their thriving prospects; however, there are certain issues yet to be faced by women such as; child-rearing, homemaking, etc. (Winn 2004). In this respect, certain responsibilities are thought to be inherent and inborn for women like childcare and housework irrespective of their earning, qualification, or employment. This state of affairs tarnishes women's dream of having vibrant and dynamic job opportunities for women. About this concern, Webster (2001) opines that roles and expectations from women vary from society to society yet it has been recorded that women tend to be held responsible for domestic duties like childcare and parenting. 
The research findings of Kapoor et al. (1999), regarding married women employees, reveal that women are in a weak position to develop and maintain a balance between job demands and family-demands and that, family-related issues are responsible for their misery. The absence of work support at home by the husbands exacerbates the situation for working women. In this connection, Rajadhyaksha and Smita (2004) explored that just 34\% of husbands were supporting their wives in routine household matters. While the figure for those who occasionally supported their wives was $24 \%$. This simply means that the majority of the population still follows the traditional stance. A study conducted in the information technology industry by Ali (2006), concludes that social support from the family as well as by the concerned organization plays a pivotal role in job facilitation for women. Raj and Mahalakshmi (2016) state that despite the several roles played by women in the family and at work, like a spouse, caretaker, parent, employee, colleague and providing service due to work pressure and stress.

The research (Memon, et al., 2020) demonstrated a positive and critical connection and effect of job life balance on satisfaction at the workplace which was acknowledged and has been predictable to past researches. Furthermore, an intervention impact of EI between WL and its satisfaction is determined. The opinions of male and female teachers also vary regarding EI and WL. It shows the gender difference in their perceptions. Professional fulfillment is the same for both gender while there is no important contrast saw among wedded and unmarried respondents in three of the cases.

In the current setting of a quickly changing climate, the essential for harmony between job and domestic routine is applauded high. It accompanies as a major test to administration and leadership impelling disappointment, clashes, ineffectiveness, and wearing down. Thus, the study recognizes the correlation between EI, socio factors, and its impact on WL. Along these lines, the socio factors affect the degree of EI and consequently push WLB moreover. In particular, it recommends that intercession pointed toward improving the Work-life of individuals, and it upgrades the degree of EI with different socio factors (Madan \& Raja, 2019).

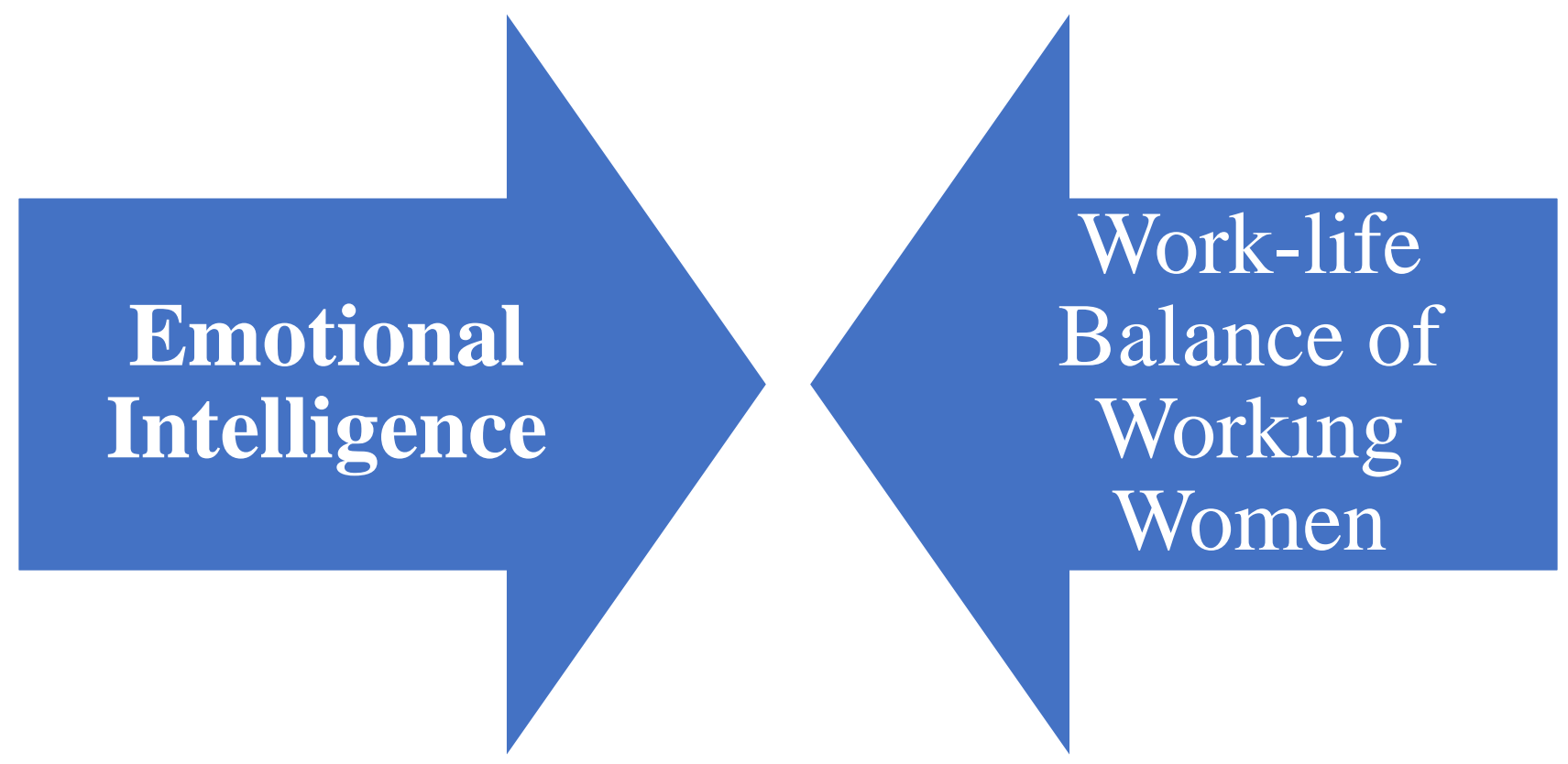

Figure 1: Conceptual Framework of EI and WLB of Working Women

Source: Authors conceptualization

\section{HYPOTHESES}

1. There is a weak level of emotional intelligence and work-life balance of working women of public sector universities in KP.

2. There is no relationship between emotional intelligence and the work-life balance of working women of public sector universities in KP.

\section{METHODOLOGY}

\section{Research design, Population, and sample}

It was a quantitative and correlational study where the survey technique was used as a data collection mechanism. The population of this study comprised six (06) public universities were five hundred and forty-seven (547) working women teachers. A sample of 330 respondents was chosen through a random sampling technique. For collecting data, a 
questionnaire survey based used as a tool for this study as it is a suitable technique to analyze the perception of human behavior (Francis et al., 2000; Francis et al., 2004).

Table 1: Respondents' Demographic Information

\begin{tabular}{|c|c|c|c|}
\hline \multicolumn{2}{|c|}{ Demographic Variables } & \multirow{2}{*}{$\begin{array}{l}\boldsymbol{F} \\
66 \\
\end{array}$} & \multirow{2}{*}{$\begin{array}{l}\% \\
20.6 \\
\end{array}$} \\
\hline Age & $25-30$ & & \\
\hline & $30-40$ & 93 & 29.1 \\
\hline & $40-50$ & 103 & 32.2 \\
\hline & 50 or above & 58 & 18.1 \\
\hline \multirow[t]{2}{*}{ Designation } & Assistant Professors & 180 & 56.2 \\
\hline & Lecturers & 140 & 43.8 \\
\hline \multirow[t]{3}{*}{ Qualification } & Masters & 29 & 9.1 \\
\hline & M.Phil. & 100 & 31.2 \\
\hline & Ph.D. & 191 & 59.7 \\
\hline \multirow[t]{4}{*}{ Experience } & $1-10$ & 93 & 29.1 \\
\hline & $10-20$ & 110 & 34.4 \\
\hline & $20-30$ & 92 & 28.8 \\
\hline & $30-40$ & 25 & 7.8 \\
\hline \multirow[t]{3}{*}{ Marital status } & Married & 135 & 42.2 \\
\hline & Single & 106 & 33.1 \\
\hline & Separated/Divorced & 79 & 24.7 \\
\hline
\end{tabular}

Table 1 shows the statistics concerning the demographic variables of the participants. The demographic variables were gender, age, designation, marital status, education, and teaching experience.

\section{Development of measuring tool}

The questionnaire was developed related to Emotional intelligence and Work-life balance with the relevant demographic descriptions of the respondents as well. The EI consisted of five factors where each factor contained five statements relevant to the theme. Thus, there were twenty-five statements in the questionnaire. The second variable work-life balance of the working women consisted of ten factors. The statements of this questionnaire were also ranked on a 5point Likert scale. To ensure the validation of research instruments, these were presented to subject experts for their opinions. They gave feedback after reviewing the questionnaire. These instruments were pilot-tested where again some minor discrepancies were removed and finally Cronbach Alpha was applied which revealed reliability of EI .84, and WLB .87 respectively. Thus both the instruments were reliable for data collection.

\section{Data collection and analysis}

The researchers collected the data in their presence to avoid any discrepancy if it happens. The respondents were requested to fill the questionnaires. The response rate was $97 \%$ as respondents returned the questionnaires. In this manner, the requisite data were collected, organized, described, and analyzed by the researchers. Descriptive and inferential statistics were applied to analyze the data. For measuring the relationship between the two variables the Pearson's $r$ generally known as 'Pearson product-moment correlation coefficient was used. Skidmore and Thompson (2011) viewed that it was the most appropriate technique for finding relationships among variables. This technique has many academic benefits as on the one hand it gives a clear picture of the phenomenon of linear relationships between and among variables. Thus, it gives a clear picture of the strong or weak relationships among variables.

\section{RESULTS}

Table 2: Level about EI of Respondents

\begin{tabular}{ccc}
\hline Levels & $\boldsymbol{F}$ & $\boldsymbol{\%}$ \\
\hline Low & 50 & 15.6 \\
\hline Medium & 80 & 25.0 \\
\hline High & 190 & 59.4 \\
\hline Total & 320 & 100.0 \\
\hline
\end{tabular}

Table 2 shows that $59.4 \%$ of the participants had a high level of emotional intelligence.

Table 3: Levels of WLB of the Respondents

\begin{tabular}{cccc}
\hline Levels & $\boldsymbol{F}$ & $\boldsymbol{\%}$ \\
\hline Low & 47 & 14.7 \\
\hline
\end{tabular}




\begin{tabular}{crr}
\hline Medium & 84 & 26.2 \\
\hline High & 189 & 59.1 \\
\hline Total & 320 & 100 \\
\hline
\end{tabular}

Table 3 is indicative of the situation where mostly women teachers develop a balance between work and home activities easily.

Table 4: Relationship between WLB and EI of University Women Teachers

\begin{tabular}{lll}
\hline Factors & $\boldsymbol{R}$ & $\boldsymbol{P}$ \\
\hline Work-life balance and Emotional intelligence & $0.951^{* *}$ & 0.01 \\
\hline
\end{tabular}

The above table reveals that there is a strong significant correlation between the Emotional Intellect and the Working Lifecycle of respondents. There is a positive correlation coefficient which shows that there is a strong relationship. The higher the scores in Emotional Intelligence: the higher the Working Life Balance of the respondents.

Table 5: Relationship between Dimensions of WLB with EI

\begin{tabular}{llll}
\hline \multirow{2}{*}{ Dimensions of WLB } & \multicolumn{2}{l}{} \\
\cline { 2 - 4 } & $\boldsymbol{N}$ & $\boldsymbol{R}$ & $\boldsymbol{p}$ \\
\hline Official Provision & 320 & 0.840 & 0.01 \\
\hline Work-Life Balance Policies & 320 & 0.848 & 0.01 \\
\hline Work Place Support & 320 & 0.826 & 0.01 \\
\hline Workload Management & 320 & 0.722 & 0.01 \\
\hline Work Expectations & 320 & 0.698 & 0.01 \\
\hline Workplace Satisfaction & 320 & 0.867 & 0.01 \\
\hline Societal Support & 320 & 0.855 & 0.01 \\
\hline Child Care & 320 & 0.862 & 0.01 \\
\hline Self-management & 320 & 0.906 & 0.01 \\
\hline Personal Life Expectations & 320 & 0.855 & 0.01 \\
\hline
\end{tabular}

Table 5 is about the relationship between the dimension of job life balance and the emotional intellect of the respondents. The statistical values show that there is a strong significant relationship between the sub-factors of WorkLife Balance and Emotional Intelligence.

Table 6: Correlation between Dimensions of EI with WLB

\begin{tabular}{llll}
\hline \multirow{2}{*}{ Sub factors of EI } & \multicolumn{3}{c}{ Work-Life Balance } \\
\cline { 2 - 4 } & $\boldsymbol{N}$ & $\boldsymbol{r}$ & $\boldsymbol{P}$ \\
\hline Emotional Self-awareness & 320 & 0.755 & 0.01 \\
\hline Self-Management & 320 & 0.855 & 0.01 \\
\hline Social Awareness & 320 & 0.869 & 0.01 \\
\hline Relationship Management & 320 & 0.895 & 0.01 \\
\hline Self-confidence & 320 & 0.904 & 0.01 \\
\hline
\end{tabular}

Table 6 is about co-relation between the dimensions of emotional power on one hand and the work-life stability of the respondents. All these sub-factors have a significant correlation with Work-Life Balance.

\section{DISCUSSION}

The study aimed to investigate the level of association of EI with the WLB among working women in the province of Khyber Pakhtunkhwa, Pakistan. It was found in the study that the higher the Emotional Intelligence the higher the WorkLife Balance among the respondents. This is pertinent to mention here that with a fast-changing world scenario work-life balance has become a challenging phenomenon for women. This is much influenced by growing prerequisites of specific jobs in all walks of life. The familial style has radically changed as in past husband was supposed to earn and the woman was to keep up the household affairs as nowadays the wife is also an earning individual of the family. However, in most cases, the wives are still performing their traditional duties at home besides being equal financial contributors to the family. Despite the enormous entry of women into the earning arena, they are still performing their traditional responsibilities at home. This is due to the cultural taboos that think of women performing household affairs at all costs. This phenomenon poses a challenging situation for the working women, hence, the issue of work-life balance.

The findings of this research reveal a strong significant correlation exists between emotional intelligence and stability of work life. This result showed that the higher scores on EI leads to a higher score on the WLB. This finding in line with the previous study done by Shylaja and Prasad (2017) who stated that EI bears a significant effect on peoples' work-life balance especially in their professional and personal lives. In this respect, many other researchers have conducted studies 
such as; Bedi and Bedi (2017) who concluded that EI fosters work-life balance in a person's life. Similarly, Thorat and Dharwadkar (2016) explored that EI served as a determinant factor for working people to properly manage their relations at the workplace and achieve a better work-life balance. Similar findings were shared by Sharma (2014) who based on a survey of 55 workers found that there is a positive relationship between EI and WLB. To add further, Srividhya and Sharmila (2014) opined that through a high level of EI working women were at a better level of handling both home and workplace-related responsibilities. Researchers Kumarasamy et al. (2016), Thorat and Dharwadkar (2016), and Shylaja and Prasad (2017) found in their respective investigations that a direct relationship exists between EI and attaining WLB, both at the management and employee level.

The findings of this study showed that all sub-factors of WLB have a strong correlation with EI. The results showed the strong relationship of Workplace satisfaction, institutional support, and self-management with EI. Those who possess a high level of EI are rarely confronted with stressful situations such as role conflict and are better at performing their respective responsibilities at the workplace and the family level. The possible reason behind this phenomenon could be that individuals with better EI levels possess a high level of motivation and interest in their work (Gupta, 2016). The findings of this study matched that of Eid (2016) who explored the relationship of employees' satisfaction with employees' performance where a better performance was observed. Similarly, Goodwin and Richards (2017) found that individuals who had no support at their workplace ultimately led to lower WLB which led to a high level of dissatisfaction for the sampled respondents. In this respect, the findings of Sharma et al. (2016) are worth-mentioning who discovered that the harder the working conditions of the employees the lesser the satisfaction and the performance. The same idea was expounded by Lee et al. (2015); Azeem and Altalhi (2015) who believe when the employees achieve balance at the workplace especially in job requirements and demands of personal life enhance the satisfaction level of the employees.

It was explored in the study that all the sub-factors of EI have a strong relationship with WLB. Self-confidence and relationship management plays a very significant role in work-life balance. Similar to that, Long et al. (2016) maintained that EL plays an integral role in services organizations, where quality is associated with the service as EI strengthens individuals to exhibit constructive behavior with co-workers, subordinates, managerial hierarchy, and even the clients as well. Furthermore, researchers like, Bedi and Bedi (2017) discovered that EI empowers an individual's level of positively perceiving work environment which in turn leads to a better level of job satisfaction.

\section{CONCLUSION AND RECOMMENDATIONS}

Balancing both work and life is an interesting debate among researchers. This aspect has posed a serious challenge to employees as to how to manage their respective personal and professional life. To increase the better productivity, efficiency, and commitment of employee's organizations will have to introduce WLB policies within their confinements. The study concluded that there is a strong relationship exists between EI and WLB. All the sub-factors of EI are strongly correlated with WLB. High-level emotional intelligence persons manage and understand their own emotions as well as that of others in a better manner that leads to better performance. It is a better way to provide better work and life balance. Therefore, it is recommended that employees may be engaged in training related to the theory and practice of EI so that they may utilize the same for the management of conflicting situations. Emotional intelligence is an ability that can be developed through training.

The researchers recommend that special attention may be given to the specific problems of the female employees in any organization as they have multiplicity roles to play besides their workplace responsibilities. There may be a clear demarcation regarding working and non-working activities. At each organizational level, the senior management the concerned officials may take active strides to formulate policies about WLB related measures to build sustainable institutions in all aspects of life. They should come up with effective and efficient emotionally balanced working culture for women that may make their personal and professional life pleasant. The authorities may focus on effectiveness and productivity rather than the length of working hours. In this respect, communication technologies and skillful timemanagement strategies may be focused on for better productivity.

Furthermore, social support may be applied as a tool for reducing stress especially in women, which empowers the latter in properly handling WLB together with familial duties. Other members of the household may extend moral support to the working women by helping them in the fulfillment of their routine life tasks. The working females may be assisted in terms of monetary support and emotional care. In the case of married working females, the role of the husband is of integral importance who may extend every possible support to the wife for achieving and maintaining a better level of WLB. Hence a sense of co-partnership between the husband and the wife may be ensured to avoid role-conflict etc.

\section{LIMITATIONS}

This study was conducted on working women teachers in KPK Province. The researchers faced problems in data collection by the participants due to the cultural barrier and COVID-19.

\section{ACKNOWLEDGEMENT}

The participation of working women is highly acknowledged in this study. There was no financial support to conduct this study. It was conducted by utilizing self-resources. 


\section{AUTHORS' CONTRIBUTION}

Dr. Sadaf Naz presented her research idea wrote abstract, introduction, methodology, conducted analysis, generated tables during analysis.

Dr. Saghiir Ahmad Ch. wrote objectives and hypotheses, discussed findings of the study with past studies, and concluded the findings. He generated hyperlinks of citations with references. He also showed his interest in formatting and proofreading papers and finalized papers according to APA Manual 7th edition. He made all revisions as suggested by the Editor and External Reviewer.

Dr. Ayesha Batool wrote a literature review, checked citations, and interpreted the analysis. She also contributed to editing and formatting. She is the Correspondence Author of the paper.

\section{REFERENCES}

1. Akintayo, D. I. (2010). Work-family conflict and organization commitment among industrial workers in $\begin{array}{llllll}\text { Nigeria. Journal of Psychology and } & \text { Counseling, }\end{array}$ https://www.researchgate.net/publication/268427843_Work-family_role_conflict_and_organizational_co mmitment_among_industrial_workers_in_Nigeria

2. Ali, N. (2006). Hi - tech women. The Asian age. http://www.nasscom. In /Nasscom/templates /NormalPage.aspx idZ49604.

3. Anand, R., \& UdayaSuriyan, G. (2010). Emotional intelligence and its relationship with leadership practices. International Journal of Business Management, 5(2), 65-76. https://d1wqtxts1xzle7.cloudfront.net/9896770/5 024-23466-1-PB.pdf?1329824557=\&response-content-

4. Austin, E. J., Saklofske, D. H., \& Egan, V. (2005). Personality, well-being and health correlates of trait emotional intelligence. Personality and Individual differences, 38(3), 547-558. https://doi.org/10.1016/j.paid.2004.05.009

5. Azeem, S. M., \& Altalhi, H. (2015). Role of perceived work-life balance and job satisfaction in developing organizational commitment among hospital employees in Saudi Arabia. International Journal of Academic Research in Business and Social Sciences, 5(12), 185-197. https://pdfs.semanticscholar.org/564b/fff7d8 Of41a6f791d673add2280e682adbb8.pdf

6. Bailyn, L. (2006). Breaking the mold: Redesigning work for productive and satisfying lives (2nd ed.). Cornell University Press.

7. Barnett, M. L. (2006). Finding a work balance between competitive communal strategies. Journal of Management Studies, 43(8) 1753-1773. https://doi.org/10.1111/j.1467-6486.2006.00661.x

8. Bedi, M., \& Bedi, K. (2017). Emotional intelligence and life satisfaction: an empirical study among managers in Indian banking sector. Amity Global Business Review, 12(4), 116-122. https://d1wqtxts1xzle7.cloudfront.net/57878830/PUBLISHED_Rethinking_Human

9. Cavazotte, F., Moreno, V., \& Hickmann, M. (2012). Effects of leader intelligence, personality and emotional intelligence on transformational leadership and managerial performance. The Leadership Quarterly, 23(3), 443455. https://doi.org/10.1016/j.leaqua.2011.10.003

10. Chaudhry, A., \& Saif, M. I. (2012). Presence and potential of emotional intelligence (EI) in organizational settings. African Journal of Business Management, 6(20), 6117-6122. https://ssrn.com/abstract=2171728

11. du Toit, A., Viviers, R., Mayer, C. H., \& Visser, D. (2017). Emotional intelligence and leadership in a South African financial services institution. South African Journal of Labour Relations, 41(1), 1-14. https://journals.co.za/doi/abs/10.10520/EJC-5522633ba

12. Eid, M. T. I. (2016). Highlighting the main factors of job satisfaction among Jordanian hospitals employees. Journal of Applied Quantitative Methods, 11(1), 15-25. http://www.jaqm.ro/issues/volume-11,issue$1 /$ pdfs/jaqm vol11 issue 1 .pdf\#page $=84$

13. Fallon, B. (2001). The loves of our lives-home and work: How can we keep them in perspective? In First APS Interest Group on the Psychology of Relationships Conference, Deakin University, Melbourne.

14. Francis, G., Neath, I., \& Surprenant, A. (2000). The cognitive psychology online laboratory. In Psychological experiments on the Internet (pp. 267-283). Academic Press. https://doi.org/10.1016/B978-012099980-4/50012$\underline{5}$

15. Francis, J., Eccles, M. P., Johnston, M., Walker, A. E., Grimshaw, J. M., Foy, R., ... \& Bonetti, D. (2004). Constructing questionnaires based on the theory of planned behaviour: A manual for health services researchers. Newcastle upon Tyne, UK: Centre for Health Services Research, University of Newcastle upon Tyne. https://openaccess.city.ac.uk/id/eprint/1735/1/

16. Frederickson, B. L. (2003). The value of positive emotions. American Scientist, 91, 330-335. https://www.americanscientist.org/sites/americanscientist.org/files/20058214332_306.pdf

17. Freidman, S. D., \& Greenhaus, J. H., (2000). Work and family, allies or enemies? What happens when business professionals confront life choices? New York Oxford Press. 
18. Gohm, C. L., \& Clore, G. L. (2002). Four latent traits of emotional experience and their Involvement in wellbeing, coping and attributional style. Cognition and Emotion 16(4), 495-518. https://doi.org/10.1080/02699930143000374

19. Goodwin, M., \& Richards, K. (2017). Best practices in healthcare management begin with self. Nursing Economic, 35(3), 152-155. http://www.self-careacademy.com/PDFs/bestbractices-healthcaremanagment.pdf

20. Grant, A. M. (2007). Enhancing coaching skills and emotional intelligence through training. Industrial and Commercial Training, 39(5), 257-266. https://doi.org/10.1108/00197850710761945

21. Greenhaus, J. H., Parasuraman, S., \& Collins, K. M. (2001). Career involvement and family involvement as moderators of relationships between work-family conflict and withdrawal from a profession. Journal of Occupational Health Psychology, 6(2), 91-100. https://doi.org/10.1037/1076-8998.6.2.91

22. Gupta, S. (2016). Emotional intelligence and work life balance of employees in the information technology industry. Arabian Journal of Business and Management Review, 6(3), 2-5. https://doi.org/10.4172/2223$\underline{5833.1000201}$

23. Jonck, P., \& Swanepoel, E. (2015). Exploring the theoretical link between cultural and emotional intelligence: A system analysis for human resource management. South African Journal of Business Management, 46(4), 77 84. https://journals.co.za/doi/abs/10.10520/EJC180432

24. Kalantari, P., Mohammadi Moghani, H., Taghibigloo, N., \& Honari, H. (2012). The relationship between emotional intelligence and physical education teachers working life quality in Zanjan. International Journal of Basic Sciences and Applied Research, 1(2), 30-34. http://www.isicenter.org

25. Kapoor, J., Bhardwaj, G., \& Pestonjee, D. M. (1999). Enquiry into the various facets of women's careers. Ahmedabad: Indian Institute of Management. http://hdl.handle.net/11718/569

26. Kidwell, B., Hardesty, D. M., Murtha, B. R., \& Sheng, S. (2011). Emotional intelligence in marketing exchanges. Journal of Marketing, 75(1), 78-95. https://doi.org/10.1509/jm.75.1.78

27. Kinnear, L. (2014). A critical analysis of the emerging models of power amongst South African women business leaders (Unpublished doctoral thesis). University of KwaZulu Natal (UKZN), Durban

28. Kirk, B. A., Schutte, N. S., \& Hine, D. W. (2008). Development and preliminary validation of an emotional Self-efficacy scale. Personality Differences, 45(5), 432-436. https://doi.org/10.1016/j.paid.2008.06.010

29. Kumarasamy, M. M., Pangil, F., \& Mohd Isa, M. F. (2016). The effect of emotional intelligence on police officers' work-life balance: The moderating role of organizational support. International Journal of Police Science \& Management, 18(3), 184-194. https://doi.org/10.1177/1461355716647745

30. Lee, J. S., Back, K. J., \& Chan, E. S. (2015). Quality of work life and job satisfaction among frontline hotel employees: A self-determination and need satisfaction theory approach. International Journal of Contemporary Hospitality Management, 27(5), 768-789. https://doi.org/10.1108/IJCHM-11-2013-0530

31. Lenaghan, J. A., Buda, R., \& Eisner, A. B. (2007). An examination of the role of emotional intelligence in work and family conflict. Journal of Managerial Issues, 19(1), 76-94. https://www.jstor.org/stable/40601194

32. Long, C. S., Yaacob, M., \& Chuen, T. W. (2016). The Impact of Emotional Intelligence on Job Satisfaction among Teachers. International Journal of Management, Accounting and Economics, 3(8), 544-552. http://www.ijmae.com/article_115377_6a83e791274a3c03d36c339aeb999ab2.pdf

33. Mostert, K. (2009). The balance between work and home: The relationship between work and home demands and ill health of employed females. SA Journal of Industrial Psychology,35(1), 145-152. http://www.scielo.org.za/scielo.php?script=sci_arttext\&pid=S2071-07632009000100016

34. Madan, C., \& Raja, S. (2019). Emotional intelligence and work life balance of employees. International Journal of Arts, Science and Humanities, 6(3), 37-43. http://www.shanlaxjournals.in/journals/index .php/sijash/article/view/250/176

35. Memon, M. Q., Khaskhely, M., \& Pitafi, A. (2020). Evaluating the mediating effect of work-life balance between emotional intelligence and job satisfaction in corporate sector. European Journal of Business and Management Research, 5(6), 1-6. https://doi.org/10.24018/ejbmr.2020.5.6.594

36. Pillay, M., Viviers, R., \& Mayer, C. H. (2013). The relationship between emotional intelligence and leadership styles in the South African petrochemical industry. SA Journal of Industrial Psychology, 39(1), 1-12. http://www.scielo.org.za/scielo.php?pid=S2071-07632013000100019\&script=sci_arttext\&tlng=es

37. Rahim, S. H. (2010). Emotional intelligence and stress: An analytical study of Pakistan banks. International Journal of Trade, Economics and Finance, 1(2), 194. http://www.ijtef.org/papers/35-C179.pdf

38. Raj, M. V., \& Mahalakshmi, A. (2016). Work life balance of women it professionals -an empirical study with reference to Bangalore city. International Journal of Business and Administration Research Review, 2(16), 168174. https://www.researchgate.net/publication/319405896

39. Rajadhyaksha, U., \& Smita, S. (2004). Tracing a timeline for work and family research in India. Economic and Political Weekly, 39(17), 1674-1680. https://www.jstor.org/stable/4414926

40. Rajesh, S., Ekambaram, K., \& Rakesh, A. (2013). Corporate sector's role in the enablement of women careers in India: An empirical study. The SIJ Transactions on Industrial, Financial \& Business Management (IFBM), 1(5), 150-158. http://www.99daydiversitychallenge.com/documents/Dr.SaundaryaRajesh-CorporateS ectorsRoleInWomen'sCareerEnablement.pdf 
41. Ruderman, M. N., Ohlott, P. J., Panzer, K., \& King, S. N. (2002). Benefits of multiple roles for managerial women. Academy of management Journal, 45(2), 369-386. https://doi.org/10.5465/3069352

42. Schwartz, A. (2011). Foster care worker's emotional responses to their work. Journal of Sociology \& Social Welfare, 38(3), 31-51. $\quad \underline{\text { https://heinonline.org/HOL/LandingPage?handle=hein.journals/jrlsasw38 }}$ $\&$ div $=28 \&$ id $=\&$ page $=$

43. Sharma, L. N. (2014). Emotional intelligence as corelate to work life balance (a case study of Sidhi MP). Global Journal of Finance and Management, 6(6), 551-556. https://www.ripublication.com/gjfmspl/gjfmv6n6_10.pdf

44. Sharma, S., Parmar, J. S., \& Chauhan, S. S. (2016). Work-related variables and work-life balance--A study of nurses in Government hospitals of Himachal Pradesh. Productivity, 57(3), 286- 292. https://doi.10.18843/IJCMS/V8I3/12

45. Shylaja, P., \& Prasad, C. J. (2017). Emotional intelligence and work life balance. IOSR Journal of Business and Management, 19(5), 18-21. https://pdfs.semanticscholar.org/bb63/4ff31c32e4cbafac82552d9ac 691278347d4.pdf

46. Skidmore, S. T., \& Thompson, B. (2011). Choosing the best correction formula for the Pearson $\mathrm{r}^{2}$ effect size. The Journal of Experimental Education, 79(3), 257-278. https://doi.org/10.1080/00220973.2010.484437

47. Srividhya, S., \& Sharmila, G. (2014). A study on importance of emotional intelligence in work life balance of women employees. GALAXY International Interdisciplinary Research Journal, 2(4), 118-123. http://internationaljournals.co.in/pdf/GIIRJ/2014/April/16.pdf

48. Thomas, L. T., \& Ganster, D. C. (1995). Impact of family-supportive work variables on work-family conflict and strain: A control perspective. Journal of Applied Psychology, 80(1), 6-15. https://doi.org/10.1037/00219010.80.1.6

49. Thorat, P., \& Dharwadkar, K. (2016). Role of emotional intelligence in managing work-life balance with special reference to bank employees in Mumbai City. International J. Res, 5(2), 24-27. http://internationaljournalofresearch.co.in/wp-content/uploads/2017/02/pooja.pdf

50. Valcour, P. M., \& Hunter, L. W. (2005). Technology, organizations, and work-life integration. In E. E. Kossek \& S. J. Lambert (Eds.), LEA's organization and management series. Work and life integration: Organizational, cultural, and individual perspectives (p. 61-84). Lawrence Erlbaum Associates Publishers. https://psycnet.apa.org/record/2004-21246-004

51. Webster, J. (2001). Getting into "good work": what opportunities does the information society offer to women? In I tech women: Meeting to-morrow, Vienna (pp. 22-23). http://citeseerx.ist.psu.edu/viewdoc/download?d oi=10.1.1.550.2804\&rep=rep1\&type=pdf

52. Y1lmaz, M., Altiok, M., Yaman, Z., Seyrek, S., Surmeli, Y., \& Sungur, M. A. (2015). Emotional intellengence in university students. Global Journal of Guidance and Counseling in Schools: Current Perspectives, 5(2), 6771. http://sproc.org/ojs/index.php/gjgc 